\title{
FOOD WEB STRUCTURE, ENERGETICS, AND IMPORTANCE OF ALLOCHTHONOUS CARBON IN A DESERT CAVERNOUS LIMNOCRENE: DEVILS HOLE, NEVADA
}

\author{
Kevin P. Wilson ${ }^{1,2}$ and Dean W. Blinn ${ }^{1,3}$
}

\begin{abstract}
Aвstract-We tested the hypothesis that allochthonous carbon is important in the diet of the endemic pupfish Cyprinodon diabolis over a 3-year period in Devils Hole, Nevada. Devils Hole is a cavernous limnocrene located in the Mojave Desert approximately $15 \mathrm{~m}$ below the land surface and receives direct solar radiation $<7 \%$ of the total time during the year. The system is dominated by filamentous cyanobacteria in the summer and supports about 15 invertebrate species and the endemic pupfish C. diabolis. We examined food web structure and measured autochthonous carbon production and entry of allochthonous carbon with funnel traps. Stable isotopes were used to compare contributions of each carbon source. Allochthonous carbon contributed $2971 \mathrm{kj} \cdot \mathrm{yr}^{-1}(60 \%)$ of the total available energy to the food web compared to only $2000 \mathrm{kj} \cdot \mathrm{yr}^{-1}$ autochthonous production. A major stochastic rain event delivered more terrestrial carbon to Devils Hole in 1 hour than annual allochthonous carbon, estimated from data collected with funnel traps. Mixing models with $\delta^{15} \mathrm{~N}, \delta^{13} \mathrm{C}$, and $\delta^{34} \mathrm{~S}$ showed a seasonal shift in diet for $C$. diabolis from filamentous cyanobacteria in the summer to the collector/gathering insect Stenelmis calida in the winter. Stenelmis tissue had high proportions of allochthonous plant carbon in the winter.
\end{abstract}

Key words: allochthonous carbon, autochthonous carbon, energetics, desert limnocrene, stable isotopes, Cyprinodon diabolis, Devils Hole, Nevada.

Studies over the past several decades have shown allochthonous carbon to be a critical energy source and a determinant of food web dynamics in lotic systems, especially light-limited, riparian communities (Minshall 1967, Fisher and Likens 1973, Cummins 1974, Benfield 1997). In contrast, few researchers have studied community energy budgets in springs or limnocrenes, even though some of these waters provide relatively constant chemical and physical conditions and may have simple food webs.

Odum (1957) reported high autochthonous production from epiphytic algae and dense stands of aquatic macrophytes in Silver Springs, Florida. In contrast, Teal (1957) reported that $76 \%$ of the total energy in Root Spring, a small limnocrene in Concord, Massachusetts, was derived from leaves, fruit, and branches of terrestrial vegetation. Tilly (1968) also reported that annual allochthonous input was 3.5 times greater than autochthonous production in the shallow, small spring pool of Cone Spring, Iowa.

Aquatic ecosystems in arid regions receive small contributions from terrestrial carbon sources. Naiman (1976) reported that allochthonous carbon contributed $<1 \%$ of the total energy budget in a small thermal spring-stream in the Mojave Desert, Calfornia, and Cushing (1997) estimated that terrestrial input contributed only $5 \%$ of the total energy in Rattlesnake Springs, a cold desert spring-stream in Washington State. Runck and Blinn (1994) did not include allochthonous input in their energy budget for Montezuma Well in the semiarid region of Arizona, but recent estimates have shown that allochthonous carbon contributes $<1 \%$ of the total energy to this large limnocrene (Blinn unpublished data).

The Devils Hole ecosystem has a relatively simple food web composed of fewer than 15 invertebrate species, and a small, endemic, cyprinodont fish (Cyprinodon diabolis, Devils Hole pupfish; Wilson 2001, Herbst 2003). Reduced water levels in the late 1960s to the mid-1970s from extensive groundwater pumping in Ash Meadows threatened the existence of the Devils Hole pupfish (Deacon and Williams 1991).

\footnotetext{
${ }^{1}$ Department of Biological Sciences, Northern Arizona University, Flagstaff, AZ 86011.

2Present address: Department of Life Sciences, University of Toronto, Scarborough Campus, 1265 Military Trail, Scarborough, Ontario M1C 1A4, Canada.

${ }^{3}$ Corresponding author. E-mail: deandiacade@comcast.net
} 
Between 1972 and 1997, the mean annual population size of this endemic pupfish was about 320, with highest densities of fish in late summer and early fall, after recruitment in the spring and early summer; 553 was the maximum number of fish reported in the last 3 decades (Douglas Threloff, Ventura, CA, personal communication). Since then, annual mean numbers of pupfish have averaged $<225$ fish, and recent estimates have been $<100$ fish (Grant Webber, Death Valley National Park, CA, personal communication; Riggs and Deacon 2004).

We examined the seasonal contributions of allochthonous and autochthonous carbon energy to the Devils Hole food web. We hypothesized that because of the cavernous nature of the system, autochthonous energy production was limited and allochthonous carbon served as a potentially important energy source in sustaining both the food web and the $C$. diabolis population during winter when algal production was reduced because of the absence of direct light. Also, we hypothesized that the observed reduction in pupfish abundance during winter was due to low productivity.

We measured (1) the physico-chemical environment of Devils Hole at bimonthly intervals over 2 years, (2) the rate of allochthonous carbon entry into Devils Hole at monthly intervals over 3.5 years, (3) autochthonous carbon production at bimonthly intervals over 1.5 years, and (4) the structure of the benthic community at bimonthly intervals over 2 years. We also examined gut contents of $C$. diabolis and used multiple stable isotopic analyses to seasonally track the flow of allochthonous and autochthonous carbon in the Devils Hole ecosystem.

\section{STUdy SITE}

Devils Hole is a deeply incised, cavernous window to the groundwater table, or a deep limnocrene (Riggs and Deacon 2004), located in the Ash Meadows National Wildlife Refuge in southern Nye county, Nevada $\left(36^{\circ} 26^{\prime \prime} \mathrm{N}\right.$, $\left.116^{\circ} 17^{\prime \prime} \mathrm{W}\right)$. The system is located in the Mojave Desert, where precipitation averages $12.2 \mathrm{~cm} \cdot \mathrm{yr}^{-1}$. Terrestrial plant species in the vicinity include Amphipappus fremontii Torr. \& Gray, Ambrosia dumosa (Gray) Payne, Atriplex confertifolia (Torr. \& Frém.) S. Wats., and Ephedra funereal Coville \& Morton (Dana
York, Death Valley National Park, CA, personal communication). The rock nettle, Eucnide urens (Parry ex Gray) Parry, and Parry's lip fern, Cheilanthes parryi (D.C. Eaton) Domin., are common along the rock walls of Devils Hole.

The pool is $833 \mathrm{~m}$ above sea level and approximately $15 \mathrm{~m}$ below the land surface. Owing to its incised morphometry, the pool receives $<4$ hours of direct light per day in the summer (June-August) and no direct light during December and January (Wilson 2001). The pool resulted from the collapse of an extensive cave system within Cambrian carbonate rock (Riggs and Deacon 2004). The opening to the rectangular surface pool at the bottom of the cavern system is relatively small-approximately $3.5 \times 22 \mathrm{~m}$. Within this opening there is yet a smaller area (approximately $2.6 \times 6.1 \mathrm{~m}$ ) at the southern end of the water-filled pool called the "spawning shelf" (Gustafson and Deacon 1998). The mean depth of the spawning shelf at the time of the study was $0.2 \mathrm{~m}\left(s_{\bar{x}}=0.08\right)$. The deep cavern system has not been completely mapped; however, it extends to an unknown depth $>60 \mathrm{~m}$ below the water surface (Gustafson and Deacon 1998).

Over $90 \%$ of the algal community is made up of filamentous cyanobacteria (Oscillatoria) Plectonema) and diatoms; Denticula elegans is the dominant diatom species (Shepard et al. 2000). The dominant invertebrates include 3 collector/gatherers including an amphipod (Hyalella sp.), a hydrobiid spring snail (Tryonia variegata), and an elmid beetle (Stenelmis calida), a predaceous dytiscid beetle (Neoclypeodytes cinctellus), and a scavenger flatworm (Dugesia dorotocephala; Herbst 2003). The pupfish is rarely more than $2 \mathrm{~cm}$ long or $0.5 \mathrm{~g}$ wet weight (Wilson 2001) and feeds largely on algae and detritus. This pupfish population has likely been isolated since the end of the Pleistocene (Soltz and Naiman 1978).

\section{Methods}

\section{Physico-chemical \\ Measurements}

Physico-chemical measurements were taken with a Hydrolab Mini-Sounde 4a along a vertical profile over the open, cavernous pool. Water temperature $\left({ }^{\circ} \mathrm{C}\right), \mathrm{pH}$, dissolved oxygen $\left(\mathrm{mg} \cdot \mathrm{L}^{-1}\right)$, percent oxygen saturation, specific conductance $\left(\mathrm{mS} \cdot \mathrm{cm}^{-1}\right)$, and total dissolved 
solids (TDS) were measured bimonthly between 12 October 1999 and 31 July 2001 at the following depths: $5 \mathrm{~cm}$ below the water surface, and at 0.5, 1.0, 2.0, 3.0, 4.0, and $4.5 \mathrm{~m}$. Water temperature, $\mathrm{pH}$, and specific conductance were measured $(n=161$ for each parameter) with a Hydrolab Mini-Sounde $4 \mathrm{a}$ throughout a $26-\mathrm{m}$ depth profile in the cavern pool on 9 June 2001. Alkalinity $\left(\mathrm{mg} \mathrm{CaCO}_{3}\right.$. $\mathrm{L}^{-1}$ ) was measured on site from the pool on 8 December 1999 and on 9 February and 6 June 2000 by the potentiometric titration method as described in Clesceri et al. (1998). Three samples each were collected on 14 October 1999, 12 December 1999, and 9 February 2000 to obtain dissolved organic carbon (DOC). Samples were filtered (Whatman GF/F $0.7 \mu \mathrm{m}$ pore), acidified ( $\mathrm{pH} 2 ; \mathrm{H}_{2} \mathrm{SO}_{4}$ ), and refrigerated for storage. DOC determinations were performed using a UV oxidation process (Phoenix 8000, Dorman).

Concentrations of orthophosphate $\left(\mathrm{O}-\mathrm{PO}_{4}\right)$, ammonia $\left(\mathrm{NH}_{4}\right)$, and nitrate/nitrite $\left(\mathrm{NO}_{3} / \mathrm{NO}_{2}\right)$ were determined $(n=3)$ on 12 October and 8 December 1999, and 9 February, 6 June, and 8 August 2000 from the spawning shelf and the pool at depths of 0.2 and $3.5 \mathrm{~m}$, respectively. Nutrient analyses were determined by colorimetry on a Lachat Quick-Chem 8000 autoanalyzer following USEPA protocol (USEPA 1993).

Daily light energy was obtained from a terrestrial quantum light sensor (LICOR Model\# 1400) placed $1 \mathrm{~m}$ above the spawning shelf. These data were transformed to mean daily light energy as $\mu \mathrm{mol} \cdot \mathrm{m}^{-2} \mathrm{~s}^{-1}$, and extrapolated to monthly energy values as $\mathrm{kj} \cdot \mathrm{m}^{-2} \mathrm{~d}^{-1}$ (Wetzel 2001). Light energy was also measured each visit with a LICOR photometer (Model\# Li-250) during indirect and direct periods of light in the pool. Light readings $(n=3$ per depth) were taken along a vertical profile $5 \mathrm{~cm}$ above the water surface, $1-2 \mathrm{~cm}$ below the water surface, and at $0.5-\mathrm{m}$ intervals to a depth of $4.5 \mathrm{~m}$.

\section{Allochthonous Input}

Allochthonous material was collected at approximately monthly intervals from 12 October 1999 until 21 April 2003 from 4 funnel traps (31.5 cm diameter opening) suspended over the following locations: (a) centered over the spawning shelf, (b) centered over the spawning shelf $2 \mathrm{~m}$ from the edge of the cavern pool,

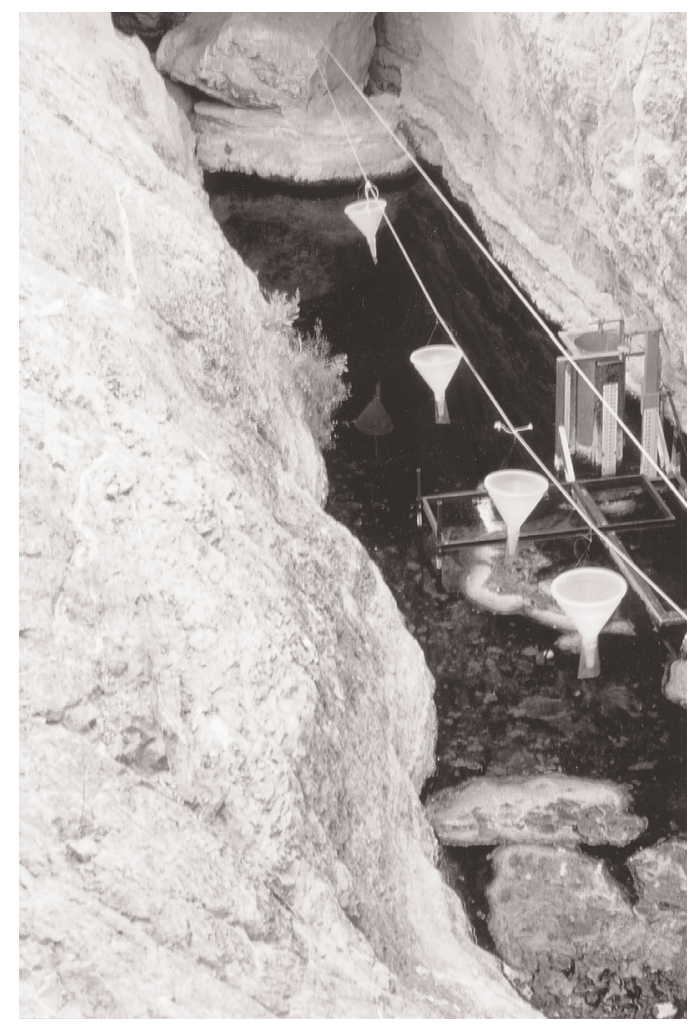

Fig. 1. Arrangement of funnel traps $(31.5 \mathrm{~cm}$ diameter $)$ in Devils Hole, Nevada. See text for detailed location of each funnel trap.

(c) centered at the junction of the spawning shelf and the cavern spring pool, and (d) centered over the cavern pool (Fig. 1). Funnel openings were about $1 \mathrm{~m}$ above the water surface in an "open" area in order to collect both direct and lateral allochthonous material. Samples were sorted into 4 categories: terrestrial plants, terrestrial insects, bat/mouse fecal pellets, and sand/detritus ( $\leq 2 \mathrm{~mm})$ —oven-dried at $60^{\circ} \mathrm{C}$ to a constant weight, and combusted at $500^{\circ} \mathrm{C}$ for 1 hour for ash-free dry mass determinations (AFDM). Input rates for allochthonous carbon mass ( $\mathrm{g}$ AFDM $\cdot \mathrm{d}^{-1}$ ) and energy $\left(\mathrm{kj} \cdot \mathrm{yr}^{-1}\right)$ were estimated for each category for each month for the open pool area $(3.5 \times 22 \mathrm{~m})$ of Devils Hole. A Phillipson oxygen microbomb calorimeter (Gentry Instruments, Aiken, SC) was used to determine energy equivalents $\left(j \cdot \mathrm{mg}^{-1}\right.$ dry weight $)$ for each of the 4 categories $(n=3$ per category; see Table 1).

Nine floating "raft" samples (each approximately $5 \mathrm{~cm}^{2}$ ) of allochthonous detritus were 
TABLE 1 . Energy equivalents $\left(\mathrm{j} \cdot \mathrm{mg}^{-1} ; n=3\right)$ determined by microbomb calorimetry for selected biotic components in the Devils Hole ecosystem. Standard errors are in parentheses.

\begin{tabular}{lc}
\hline Biotic component & $\begin{array}{c}\text { Energy equivalent } \\
\left(\mathrm{j} \cdot \mathrm{mg}^{-1}\right)\end{array}$ \\
\hline Oscillatoria/Plectonema & $15.8(0.8)$ \\
Spirogyra & $13.0(1.5)$ \\
Diatom/detritus & $12.5(1.2)$ \\
Sand/detritus (funnel traps) & $11.9(2.9)$ \\
Allochthonous funnel plants & $11.2(1.4)$ \\
Tryonia variegata & $18.8(4.9)$ \\
Hyalella sp. & $17.5(1.7)$ \\
Stenelmis calida & $17.4(2.5)$ \\
Miscellaneous invertebrates & $17.7(2.1)$ \\
Dugesia sp. & $20.1(0.8)$ \\
Allochthonous funnel insects & $17.6(1.7)$ \\
Funnel bat/mouse fecal pellets & $20.1(3.7)$ \\
Cyprinodon diabolis & $16.5(0.6)$ \\
\hline
\end{tabular}

collected with a ring net ( $>2 \mathrm{~mm}$ mesh) over the spawning shelf in Devils Hole on 5 September 2001, two days following an intense regional thunderstorm that delivered large amounts of outside carbon into Devils Hole. Ash-free dry mass estimates were made for each detrital sample as outlined above. Invertebrates were not separated in these analyses.

\section{Autochthonous Production}

Three circular, clear Plexiglass ${ }^{\circledR}$ chambers $(14.6 \mathrm{~cm}$ inner diameter and $7.5 \mathrm{~cm}$ high) equipped with a dissolved oxygen (DO) probe (YSI Model\# 55) were used to measure photosynthetic rate and respiration rate of benthic algae, following Bott et al. (1978). Primary production estimates were conducted bimonthly from 9 December 1999 to 7 June 2001 between 1000 hours and 1530 hours.

Each DO probe was calibrated and inserted into a chamber with $2 \mathrm{~L}$ of filtered $(56 \mu \mathrm{m}$ pore size) Devils Hole water. One algae-covered cobble was placed in each chamber, and each chamber was sealed with an airtight Plexiglass ${ }^{\circledR}$ lid. Each cobble was visually inspected and macroinvertebrates were removed. Surface area was estimated by averaging 3 length and 3 width measurements of each rock. Chambers were placed into Devils Hole to maintain in situ water temperatures, and photosynthetic rates were measured for 1 hour within each chamber. Each chamber was then covered with a light-tight black bag and allowed to incubate again for 1 hour to measure rates of respiration (R). Measurements of dissolved oxygen $\left(\mathrm{mg} \cdot \mathrm{L}^{-1}\right)$, percent oxygen saturation, temperature $\left({ }^{\circ} \mathrm{C}\right)$, and light intensity ( $\mu$ mols . $\mathrm{m}^{-2} \mathrm{~s}^{-1}$ ) were recorded every $10-15$ minutes. After the autochthonous production measurements were collected, the biotic material on the cobble in each chamber was scraped into a Whirl-Pak ${ }^{\mathrm{TM}}$ and placed on ice in the dark, and ash-free dry mass determinations were made for each chamber. Estimates of net primary production (NPP) and gross primary production (GPP) were calculated as $\mathrm{mg} \mathrm{O}_{2} \cdot \mathrm{m}^{-2} \mathrm{~h}^{-1}$ and converted into $\mathrm{kj} \cdot \mathrm{m}^{-2} \mathrm{~d}^{-1}$ as described by Bott (1996).

Photosynthetic rates $\left(\mathrm{O}_{2}\right.$ evolved $)$ were estimated ( $n=2$ trials) for the filamentous cyanobacteria (Oscillatoria/Plectonema) and the green alga Spirogyra to determine the oxygen contribution of each. Strands of cyanobacteria $(0.4 \mathrm{~g}$ AFDM, $\left.s_{\bar{x}}=0.03\right)$ and Spirogyra $(0.21 \mathrm{~g}$ AFDM, $\left.s_{\bar{x}}=0.02\right)$ were rinsed of other algal material with Devils Hole water and placed separately into the photosynthetic chambers using the same protocol as described above. Net production was determined for both types of strands. $\mathrm{O}_{2}$ evolved was used to estimate carbon with methods described by Bott (1996).

\section{Benthic Collections}

Bimonthly benthic samples $(n=16)$ were collected on the spawning shelf between 12 October 1999 and 31 July 2001 with a 10-cmdiameter (cross-sectional area $=0.0078 \mathrm{~m}^{2}$ ) cylindrical stovepipe. The stovepipe contained two $30-\mathrm{cm}$ sections, so it could be extended to $60 \mathrm{~cm}$ for deeper collections. A stiff-bristled brush (plastic) was used to disturb and clean each substrate down to about $2 \mathrm{~cm}$, and the suspended material was aspirated from within the stovepipe. Collections were placed on ice in the dark and analyzed within 48 hours. Samples were sorted under a dissecting scope into 7 categories: filamentous cyanobacteria, diatoms and fine detritus, Spirogyra, Hyalella, T. variegata, S. calida, and miscellaneous invertebrates (including $N$. cinctellus, chironomids, and oligochaetes). Densities for each species were recorded and each species/category was sorted into separate crucibles for AFDM determinations as above.

Because of the nocturnal behavior of $D$. dorotocephala, a $20 \times 20$-cm template was employed to estimate densities and standing mass of this flatworm. Estimates were conducted 1 hour after sunset at bimonthly intervals from 
August 2000 through June 2001. Each template was randomly placed at 20 locations on the spawning shelf in each sampling period. Flatworms within the template were counted and mass and energy equivalents $\left(\mathrm{j} \cdot \mathrm{mg}^{-1}\right.$ dry weight) were determined in the laboratory as outlined above (see Table 1).

\section{Cyprinodon diabolis Gut Analyses}

Gut contents of pupfish were analyzed on 5 dates between October 1999 and June 2001. Gut length and gut fullness were determined for each fish. Guts were entirely dissected and contents were homogenized in water on a microscope slide and identified with a compound microscope (100X). Percentage volume of $100 \%$ stomach fullness was estimated visually for each item following protocols of Minckley and Deacon (1975). The number of individuals for each invertebrate taxon within each gut were also counted.

\section{Stable Isotopes}

Stable isotopes were used to show general trophic structure in the Devils Hole ecosystem and to delineate energy sources utilized by pupfish. Multiple stable isotopic analyses were conducted for carbon $\left(\delta^{13} \mathrm{C}\right)$, nitrogen $\left(\delta^{15} \mathrm{~N}\right)$, and sulfur $\left(\delta^{34} \mathrm{~S}\right)$ on the same fish used for diet analyses. Numerically important biota in the Devils Hole food web, allochthonous plant and animal material from funnel traps, and Eucnide urens foliage submerged in Devils Hole for 3 weeks were analyzed. Excess carbonate was removed with concentrated $0.1 \mathrm{~N}$ $\mathrm{HCl}$ (modified protocol from Bosley and Wainright 1999), and the soft body tissue of T. variegata was removed from shells for isotopic analysis. Isotope samples were separated into summer (June and August) and winter (December) collections. Oven-dried, ground samples were analyzed for carbon $\left(\delta^{13} \mathrm{C}\right)$ and nitrogen $\left(\delta^{15} \mathrm{~N}\right)$ on a Finnigan Delta Plus XI ${ }^{\circledR}$ mass spectrometer at the Colorado Plateau Stable Isotope Laboratory at Northern Arizona University, Flagstaff. All $\delta^{34} \mathrm{~S}$ analyses were conducted at the Environmental Isotope Laboratory, University of Waterloo, Ontario, Canada. Isotope values were expressed as parts per million (\%o) deviation from a standard. PeeDee limestone was the standard for carbon, air for nitrogen, and the Canyon Diablo meteorite for sulfur (Peterson and Fry 1987). Multisource models were used to partition food source proportions for 3 target species (C. diabolis, D. dorotocephala, S. calida) and 9 sources. The program IsoSource version 1.3.1 (Phillips and Gregg 2003) provided probabilities for combinations of multiple sources using multiple isotopes, given a target mixture.

To correct for trophic enrichment, offsets of $3.4 \%$ for $\delta^{15} \mathrm{~N}$ and $0.8 \%$ for $\delta^{13} \mathrm{C}$ were used for source signals for each target species with each model (Minigawa and Wada 1984, Vander Zanden and Rasmussen 2001, Mantel et al. 2004). Tolerance (accepted error around a target mixture) was set at $1 \%$ except for $S$. calida for which we used $2.5 \%$ and $3.5 \%$ for summer and winter, respectively, and C. diabolis for which we used $2.0 \%$ for winter. These tolerance values were the minimum tolerances that produced any possible mixtures (solutions). Source increments or the level of partitioning among sources was set at $2 \%$ for each model.

\section{Statistical Analyses}

Data were analyzed using JMP-start statistical software, (SAS Institute, Inc. 1989-1999). A Shipiro-Wilks' W-test of normality was used to test for homogeneity of variances. There were no statistical differences in biomass among funnel trap placements for allochthonous carbon, so traps were pooled for each collection date. One-way analysis of variance (ANOVA) was used to test differences between summer and winter isotope signals. A linear regression was used to examine the correlation between light energy and NPP to extrapolate photosynthetic rates in Devils Hole throughout the year.

\section{Results}

\section{Physico-chemical \\ Environment}

Most physico-chemical features within the Devils Hole cavern pool were remarkably stable throughout the study (Table 2). Average temporal and spatial water temperatures remained high $\left(33.5^{\circ} \mathrm{C}, s_{\bar{x}}=0.01, n=360\right)$; dissolved oxygen concentrations $\left(3.6 \mathrm{mg} \cdot \mathrm{L}^{-1}, s_{\bar{x}}\right.$ $=0.2, n=360)$ and percent oxygen saturation $\left(51.3 \%, s_{\bar{x}}=2.5, n=360\right)$ were low. Values for water temperature, $\mathrm{pH}$, and specific conductance did not deviate more than $1 \%$ from the mean throughout the top $4-5 \mathrm{~m}$ of the water column throughout the study. Likewise, 
TABLE 2. Seasonal mean physico-chemical features for Devils Hole, Nevada, at approximately bimonthly intervals between 12 October 1999 and 31 July $2001(n=294$ unless otherwise indicated). $\mathrm{O}-\mathrm{PO}_{4}, \mathrm{NO}_{3}$, and $\mathrm{NH}_{3}$ values were taken from Wilson (2001). Standard errors are in parentheses.

\begin{tabular}{lc}
\hline Physico-chemical character & Seasonal mean \\
\hline Water temperature $\left({ }^{\circ} \mathrm{C}\right)$ & $33.5(0.01)$ \\
Dissolved oxygen $\left(\mathrm{mg} \cdot \mathrm{L}^{-1}\right)$ & $3.6(0.2)$ \\
$\%$ oxygen saturation & $51.3(2.5)$ \\
Dissolved organic carbon & \\
$\quad\left(\mathrm{mg} \cdot \mathrm{L}^{-1} ; n=9\right)$ & $0.735(0.147)$ \\
Specific conductance $\left(\mathrm{mS} \cdot \mathrm{cm}^{-1}\right)$ & $659(4.0)$ \\
Total dissolved solids & \\
$\quad\left(\mathrm{mg} \cdot \mathrm{L}^{-1} ; n=165\right)$ & $428(0.002)$ \\
Alkalinity $\left(\mathrm{mg} \mathrm{CaCO} 3 \cdot \mathrm{L}^{-1} ; n=16\right)$ & $262(2.6)$ \\
$\mathrm{pH}$ & $7.3(0.01)$ \\
$\mathrm{O}-\mathrm{PO}\left(\mu \mathrm{g} \cdot \mathrm{L}^{-1} ; n=12\right)$ & $4(2.6)$ \\
$\mathrm{NO}_{3}\left(\mu \mathrm{g} \cdot \mathrm{L}^{-1} ; n=15\right)$ & $245(152)$ \\
$\mathrm{NH}_{3}\left(\mu \mathrm{g} \cdot \mathrm{L}^{-1} ; n=15\right)$ & $18.6(9)$ \\
\hline
\end{tabular}

on 9 June 2001 , water temperature $\left(33.6^{\circ} \mathrm{C}, s_{\bar{x}}\right.$ $=0.003), \mathrm{pH}\left(7.0, s_{\bar{x}}=0.004\right)$, and specific conductance $\left(0.64 \mathrm{mS} \cdot \mathrm{cm}^{-1}, s_{\bar{x}}=0.05\right)$ deviated $<1 \%$ from their means in the 26 -m water column of the pool. Only nutrient concentrations were variable during the study (Table 2).

The cavernous ecosystem of Devils Hole received direct solar radiation $<7 \%$ of the total time during the year. For the remainder of the time, only indirect light reached the water surface. No direct light reached the upper spawning shelf during the months of December and January, and only about 10 minutes of direct light per day reached the upper shelf during February. In April, there were $<2$ hours of direct light per day on the shelf, approximately 3.5 hours per day in June, and about 3 hours per day in August. On the October collection date, direct light intercepted the upper shelf for about 1.2 hours. Light typically intercepted the spawning shelf between 1200 hours and 1600 hours.

Light energy at the water surface of the pool in Devils Hole averaged about $232 \mu \mathrm{mol}$ - $\mathrm{m}^{-2} \mathrm{~s}^{-1}\left(s_{\bar{x}}=4\right)$ or a total of $231,290 \mathrm{kj}$. $\mathrm{m}^{-2} \mathrm{~d}^{-1}$ near summer solstice and only about 9 $\mu \mathrm{mol} \cdot \mathrm{m}^{-2} \mathrm{~s}^{-1}\left(s_{\bar{x}}=0.2\right)$ or a total of $9165 \mathrm{kj} \cdot$ $\mathrm{m}^{-2} \mathrm{~d}^{-1}$ near winter solstice (Fig. 2). Near summer solstice, portions of the spawning shelf with indirect light averaged about $30 \mu \mathrm{mol}$. $\mathrm{m}^{-2} \mathrm{~s}^{-1}$, and sections of the shelf with direct light averaged about $1730 \mu \mathrm{mol} \cdot \mathrm{m}^{-2} \mathrm{~s}^{-1}$. Direct light energy at $1 \mathrm{~m}$ below the pool surface averaged $1326 \mu \mathrm{mol} \cdot \mathrm{m}^{-2} \mathrm{~s}^{-1}\left(s_{\bar{x}}=81\right)$, while

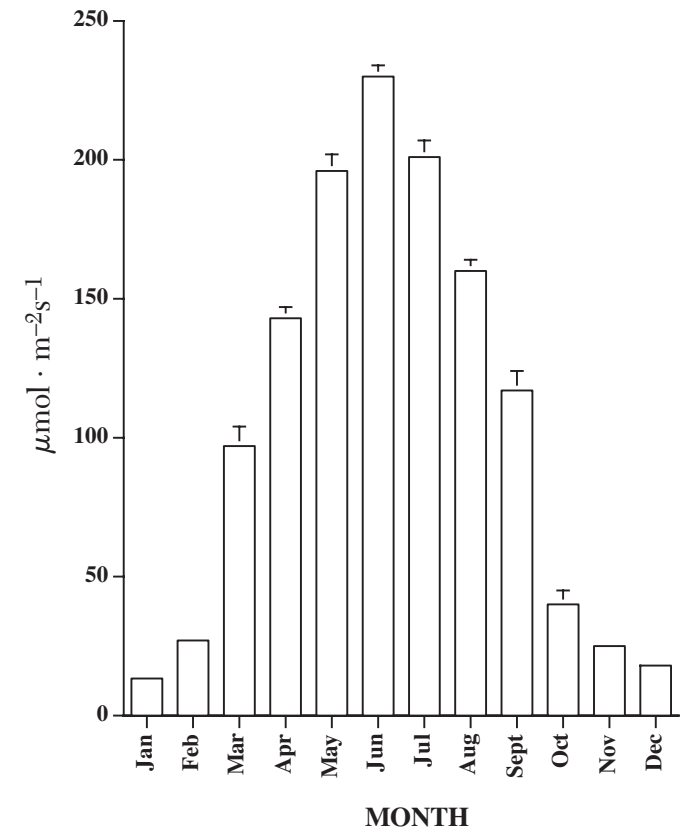

Fig. 2. Monthly mean total light energy $\left(\mu \mathrm{mol} \cdot \mathrm{m}^{-2} \mathrm{~s}^{-1}\right)$ received by the spawning shelf at Devils Hole, Nevada, during 2000. Bars represent 1 standard error.

indirect light averaged $27 \mu \mathrm{mol} \cdot \mathrm{m}^{-2} \mathrm{~s}^{-1}\left(s_{\bar{x}}=\right.$ 6 ), or about $75 \%$ of the light received on the spawning shelf. Direct and indirect light at 2 $\mathrm{m}$ and $3 \mathrm{~m}$ below the pool's surface averaged about $70 \%$ and $50 \%$, respectively, of the light received on the spawning shelf. The greatest rate of increase in light energy occurred between February and March, and the greatest rate of decrease occurred between September and October (Fig. 2), because of the orientation of the opening.

\section{Allochthonous Inputs}

Allochthonous carbon contributed about $191 \mathrm{~g} \cdot \mathrm{yr}^{-1}$ AFDM or $2971 \mathrm{kj}$ annually to the Devils Hole ecosystem during the 3.5-year study (Table 3). Allochthonous input was low from November through February and highest from June through September, with over 35\% of the total annual carbon entering during June and July. Total outside carbon input averaged about $0.1 \mathrm{~g}$ AFDM $\cdot \mathrm{d}^{-1}\left(s_{\bar{x}}=0.03\right)$ or $1293 \mathrm{j} \cdot \mathrm{d}^{-1}\left(s_{\bar{x}}=413\right)$ from November through February, and about $1 \mathrm{~g} \mathrm{AFDM} \cdot \mathrm{d}^{-1}\left(s_{\bar{x}}=\right.$ $0.1)$ or $15,855 \mathrm{j} \cdot \mathrm{d}^{-1}\left(s_{\bar{x}}=1222\right)$ from June through September. Allochthonous insects contributed nearly $45 \%$ of the mass and $51 \%$ of 


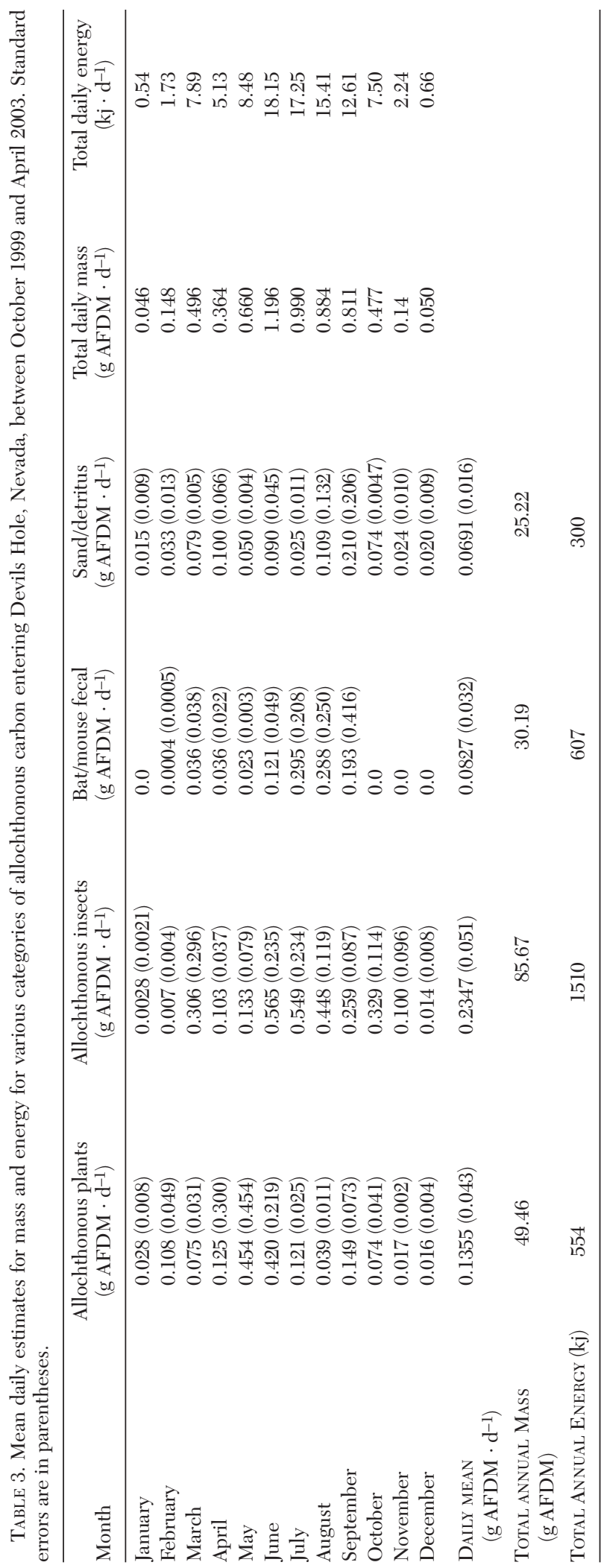


the energy in the cavern pool throughout the year, while terrestrial plants contributed about $26 \%$ of the mass or $18.6 \%$ of the energy, and sand/detritus contributed about $13 \%$ of the mass or $10 \%$ of the energy.

An intense, localized thunderstorm on 3 September 2001 delivered over $230 \mathrm{~g}$ AFDM $\cdot \mathrm{m}^{-2}\left(s_{\bar{x}}=19.4\right)$ of coarse carbon to the spawning shelf via a drainage gulley leading into Devils Hole. Much of the delivered carbon remained floating on the surface. The event occurred within a 1 -hour period (L. Manning, Death Valley National Park, personal communication). This was the only major delivery of outside energy by storm events during the 3.5-year period.

\section{Autochthonous Inputs}

Net primary production (NPP) during periods of summer direct light averaged $3.4 \mathrm{mg} \mathrm{C}$ $\cdot \mathrm{m}^{-2} \mathrm{~h}^{-1}\left(s_{\bar{x}}=0.74 ; n=8\right)$ runs during June and August at average solar radiation levels of $1917 \mu \mathrm{mol} \cdot \mathrm{m}^{-2} \mathrm{~s}^{-1}\left(s_{\bar{x}}=28\right)$, whereas NPP under winter indirect light conditions averaged only $0.74 \mathrm{mg} \mathrm{C} \cdot \mathrm{m}^{-2} \mathrm{~h}^{-1}\left(s_{\bar{x}}=0.2 ; n=8\right)$ runs during December and February at average solar radiation levels of $79 \mu \mathrm{mol} \cdot \mathrm{m}^{-2} \mathrm{~s}^{-1}$ $\left(s_{\bar{x}}=8\right)$. NPP during summer indirect light averaged $0.64 \mathrm{mg} \mathrm{C} \cdot \mathrm{m}^{-2} \mathrm{~h}^{-1}\left(s_{\bar{x}}=0.24\right)$ in light regimes ranging from 60 to $182 \mu \mathrm{mol}$. $\mathrm{m}^{-2} \mathrm{~s}^{-1}$. NPP was greater in trials with filamentous cyanobacteria mats $(0.33 \mathrm{mg} \mathrm{C}$. $\mathrm{m}^{-2} \mathrm{~h}^{-1}, s_{\bar{x}}=0.06, n=2$ ) than in trials with the filamentous green alga, Spirogyra $(0.24 \mathrm{mg}$ $\left.\mathrm{C} \cdot \mathrm{m}^{-2} \mathrm{~h}^{-1}, s_{\bar{x}}=0.02, n=2\right)$.

Gross primary production (GPP) averaged $7 \mathrm{mg} \mathrm{C} \cdot \mathrm{m}^{-2} \mathrm{~h}^{-1}\left(s_{\bar{x}}=2\right)$ in summer direct light, $1.2 \mathrm{mg} \mathrm{C} \cdot \mathrm{m}^{-2} \mathrm{~h}^{-1}\left(s_{\bar{x}}=0.3\right)$ in winter indirect light, and $3.5 \mathrm{mg} \mathrm{C} \cdot \mathrm{m}^{-2} \mathrm{~h}^{-1}\left(s_{\bar{x}}=1.1\right)$ throughout the year. Community respiration $(\mathrm{R})$ averaged $4.3 \mathrm{mg} \mathrm{O}_{2} \cdot \mathrm{h}^{-1}\left(s_{\bar{x}}=1.1\right)$ in summer direct light, $1.7 \mathrm{mg} \mathrm{O}_{2} \cdot \mathrm{h}^{-1}\left(s_{\bar{x}}=0.7\right)$ in winter indirect light, and $3.6 \mathrm{mg} \mathrm{O} \mathrm{O}_{2} \cdot \mathrm{h}^{-1}\left(s_{\bar{x}}=0.5\right)$ throughout the year.

Mean photosynthetic efficiency (i.e., conversion of light energy to algal carbon energy) during direct summer light was $0.9 \%\left(s_{\bar{x}}=\right.$ $0.1)$ and $1.9 \%\left(s_{\bar{x}}=0.4\right)$ during winter indirect light. Energy derived from NPP in Devils Hole during direct summer light averaged $33.4 \mathrm{j}$. $\mathrm{m}^{-2} \mathrm{~d}^{-1}\left(s_{\bar{x}}=6.5\right)$ and $5.8 \mathrm{j} \cdot \mathrm{m}^{-2} \mathrm{~d}^{-1}\left(s_{\bar{x}}=1.4\right)$ during winter and summer indirect light. Trials with light levels $<50 \mu \mathrm{mols} \cdot \mathrm{m}^{-2} \mathrm{~s}^{-1}$ typically generated $<1.2 \mathrm{j} \cdot \mathrm{m}^{-2} \mathrm{~d}^{-1}$ of energy from autochthonous algal production.

Based on energy values generated from autochthonous algal production and daily light energy measurements in Devils Hole, we estimated an annual net autochthonous algal production of $1400 \mathrm{kj}$ on the spawning shelf $(15.8$ $\mathrm{m}^{2}$ ) under relatively optimal, clear sky conditions. Energy generated from the total photosynthetic surface area in Devils Hole (spawning shelf + photic zone on cavern sidewalls $\left[34 \mathrm{~m}^{2}\right]$ ) may reach a maximum of $3000 \mathrm{kj}$ annually. However, a more realistic primary autochthonous energy estimate for the entire Devils Hole ecosystem may be somewhere between values for the spawning shelf and entire ecosystem, or about $2000 \mathrm{kj} \cdot \mathrm{yr}^{-1}$. The energy contribution from phytoplankton was negligible because phytoplankton densities were low (<2 cells $\cdot \mathrm{L}^{-1}$, Wilson 2001).

When indirect and direct light trials were combined, the relationship between light energy and NPP was

$$
\begin{gathered}
\mathrm{NPP}=0.001 \cdot \text { light energy }+0.282 \\
\left(R^{2}=0.56, n=42, P<0.0001, F=89.6\right) . \\
\text { Benthic Mass and Energy }
\end{gathered}
$$

Average ash-free dry mass of the benthic community varied seasonally, with highest levels occurring in June-August and declining in October (Table 4). Lowest in situ standing mass was measured during the winter and early spring. Nearly $45 \%$ of the total annual mass was attributed to filamentous cyanobacteria, about $27 \%$ to diatom/detritus, and $28 \%$ to invertebrates; Tryonia variegata made up over $80 \%$ of the invertebrate mass. Nearly $57 \%$ $\left(2788 \mathrm{kj} \cdot \mathrm{m}^{-2}, s_{\bar{x}}=53\right)$ of the energy in the benthos was filamentous cyanobacteria, 23\% $\left(1346 \mathrm{kj} \cdot \mathrm{m}^{-2}, s_{\bar{x}}=25\right)$ was diatom/detritus, and $3 \%\left(37 \mathrm{kj} \cdot \mathrm{m}^{-2}, s_{\bar{x}}=5.2\right)$ was invertebrate mass. Filamentous green algae, namely Spirogyra, appeared during April, but disappeared by August, when direct light no longer intercepted the spawning shelf.

Based on estimates from the $20 \times 20$-cm templates at night, the scavenger flatworm $(D$. dorotocephala) contributed an average annual mass of $0.29 \mathrm{~g}$ AFDM $\cdot \mathrm{m}^{-2}\left(s_{\bar{x}}=0.02\right)$ or 0.5 $\mathrm{kj} \cdot \mathrm{m}^{-2}\left(s_{\bar{x}}=0.23\right)$. Lowest densities of flatworms were found during summer and fall, and highest numbers were recorded during winter and spring. Flatworm densities averaged 50 animals $\cdot \mathrm{m}^{-2}$ on 8 December 2000 


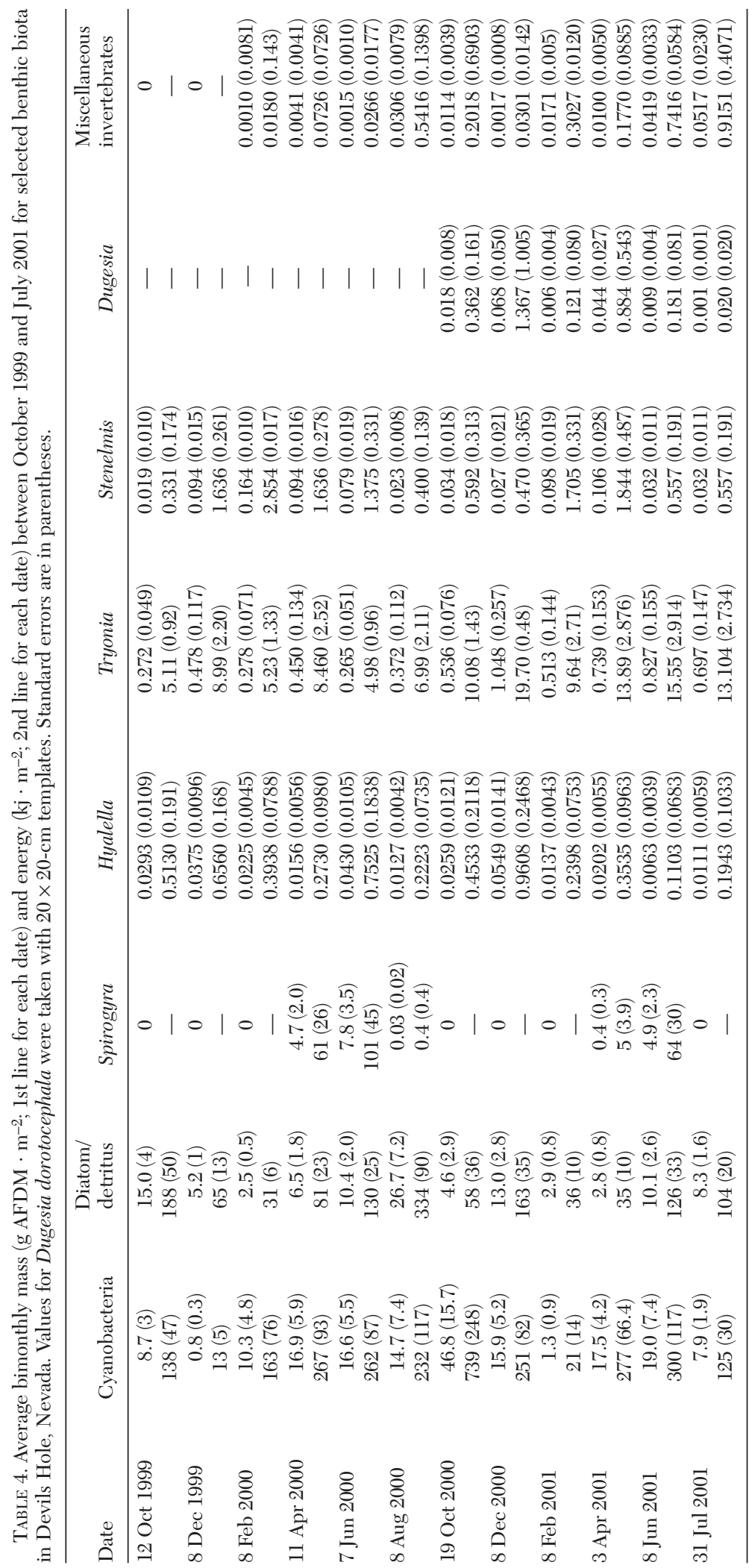


TABLe 5. Percent frequency of gut contents and gut fullness for Cyprinodon diabolis collected in Devils Hole, Nevada, during 1999, 2000, and 2001. Standard errors are in parentheses.

\begin{tabular}{lccccc}
\hline & 15 Oct 1999 & 11 Feb 2000 & 10 Aug 2000 & 10 Dec 2000 & 9 Jun 2001 \\
& $n=12$ & $n=6$ & $n=6$ & $n=3$ & $n=3$ \\
\hline Inorganic matter $\left(\mathrm{CaCO}_{3}\right)$ & $52(5)$ & $74(4)$ & $61(3)$ & $70.0(7)$ & $59(5)$ \\
Filamentous cyanobacteraia & $5(3)$ & $0.1(0.1)$ & $3(2)$ & $2(2)$ & $2(1)$ \\
Colonial cyanobacteria & $7(5)$ & 0 & $2(1)$ & $0.5(0.5)$ & 0 \\
Diatoms & $14(3)$ & $7(3)$ & $16(3)$ & $2(1)$ & $34(4)$ \\
Other algae & $1(1)$ & $1(1)$ & $1(1)$ & $1(1)$ & 0 \\
Allochthonous plants/detritus & $0.1(0.1)$ & $1.9(1)$ & 0 & $6(6)$ & $1(1)$ \\
Stenelmis calida & $16.9(11)$ & $2(2)$ & 0 & $15(16)$ & 0 \\
Hyalella sp. & $2(2)$ & $7(4)$ & $15(7)$ & $3(3)$ & 0 \\
Tryonia variegata & 0 & $1(1)$ & 0 & 0 & $4(4)$ \\
Dugesia sp. & $2(2)$ & 0 & $1(1)$ & $0.5(0.5)$ & 0 \\
Neoclypeodytes cinctellus & 0 & $6(6)$ & $1(1)$ & 0 & 0 \\
GuT FulLNESS $(\%)$ & $60(12)$ & $84(7)$ & $92(4)$ & $87(18)$ & $88(16)$ \\
\hline
\end{tabular}

and $<4$ animals $\cdot \mathrm{m}^{-2}$ on 8 June 2001 and 31 July 2001. Collections taken with the stovepipe during the day yielded considerably lower D. dorotocephala mass $\left(<0.1 \mathrm{~g}\right.$ AFDM $\left.\cdot \mathrm{m}^{-2}\right)$ and energy $\left(<0.00001 \mathrm{kj} \cdot \mathrm{m}^{-2}\right)$.

\section{Cyprinodon diabolis Gut Analyses}

Gut fullness for C. diabolis averaged $82 \%$ $\left(s_{\bar{x}}=13, n=30\right)$ throughout the study (Table 5 ). The most common item was $\mathrm{CaCO}_{3}$ (inorganic particulate matter), which averaged $63 \%$ $\left(s_{\bar{x}}=4\right)$ of the observed contents, with highest percentages during the winter. Diatoms were also in pupfish guts, averaging $14.6 \%\left(s_{\bar{x}}=\right.$ $5.5)$; summer values averaged $21 \%$ and winter values averaged $<7 \%$. Cyanobacteria and filamentous green algae averaged $<2 \%\left(s_{\bar{x}}=0.4\right)$ of the observed diet contents. Percentage of allochthonous plants $\left(<2 \%, s_{\bar{x}}=1.1\right)$ was typically low, but tended to be higher in the winter (Table 5). No allochthonous insects were recognized in the guts.

Stenelmis calida and Hyalella were the numerically important invertebrates in the pupfish diet. Combined, they averaged $6 \%\left(s_{\bar{x}}=\right.$ 2 ) of the observed gut contents. The average number of each invertebrate found in the pupfish diet across the 5 sampling dates in order of abundance included S. calida (1.6 individuals, $\left.s_{\bar{x}}=0.8\right)$, Hyalella sp. (0.4 individuals, $s_{\bar{x}}$ $=0.2), D$. dorotocephala $\left(0.4\right.$ individuals, $s_{\bar{x}}=$ $0.1), N$. cinctellus (0.2 individuals, $\left.s_{\bar{x}}=0.1\right)$, and $T$. variegata (0.1 individuals, $\left.s_{\bar{x}}=0.1\right)$. On the June sampling date, we observed 1 pupfish (3.4 mm total length) in the gut of another pupfish $(25.5 \mathrm{~mm})$.

\section{Stable Isotopes}

Autotrophic primary producers showed no significant change in isotopic signals $\left(\delta^{15} \mathrm{~N}\right.$, $\delta^{13} \mathrm{C}, \delta^{34} \mathrm{~S}$ ) between summer and winter (Table 6). However, there was a significant $(n=29, F$ $=27.38, P<0.0001)$ enrichment in $\delta^{13} \mathrm{C}$ from winter $(24.8 \%$ ) to summer $(28.2 \%$ ) for C. diabolis. $\delta^{15} \mathrm{~N}$ signals for $C$. diabolis were trophically similar between winter and summer, and $\delta^{34} \mathrm{~S}$ signals were more enriched in summer $(12.4 \% 0)$ than in winter $(10.5 \%$ ), but not significantly.

$\delta^{15} \mathrm{~N}$ values for allochthonous plants were significantly more enriched $(n=3, F=11.78$, $P=0.019)$ in summer $(8.2 \%$ ) than in winter $(5.7 \%)$, whereas there was no significant difference for $\delta^{13} \mathrm{C}$ and $\delta^{34} \mathrm{~S}$ values between seasons. There were no significant seasonal differences in allochthonous insects for $\delta^{13} \mathrm{C}$, but allochthonous insects were trophically higher during summer with $\delta^{15} \mathrm{~N}$ values increasing from $7.4 \%$ in winter to $9.6 \%$ in summer (Table 6).

IsoSource mixing models with 3 isotope systems $\left(\delta^{15} \mathrm{~N}, \delta^{13} \mathrm{C}, \delta^{34} \mathrm{~S}\right)$ revealed a shift in diet between summer and winter for $C$. diabolis and S. calida (Table 7). Both organisms relied heavily on autochthonous energy sources during summer and shifted to allochthonous sources in winter. The pupfish shifted from high consumption of filamentous cyanobacteria $(44 \%)$ during summer to low consumption of cyanobacteria during winter. Pupfish utilization of S. calida increased from $15 \%$ in summer to $51 \%$ in winter. Mixing models showed that Hyalella and D. dorotocephala together contributed about $23 \%$ of the pupfish's summer 
TABLE 6. Multiple isotope $\left(\delta^{15} \mathrm{~N}, \delta^{13} \mathrm{C}, \delta^{34} \mathrm{~S}\right)$ analyses for selected biotic components of the Devils Hole food web. Subm-plant = submerged allochthonous Eucnide urens foliage. Standard deviations and sample sizes are in parentheses.

\begin{tabular}{|c|c|c|c|}
\hline Biotic component & $\% \circ \delta^{15} \mathrm{~N}$ & $\% o \delta^{13} \mathrm{C}$ & $\% \circ \delta^{34} \mathrm{~S}$ \\
\hline Diatom/detritus (summer) & $4.2(0.3, n=6)$ & $-17.2(0.7 ; n=6)$ & $12.3(1.8, n=4)$ \\
\hline Diatom/detritus (winter) & $4.7(0.3, n=8)$ & $-16.0(1.2, n=8)$ & $12.6(2.6, n=3)$ \\
\hline Filamentous cyanobacteria (summer) & $5.5(1.1, n=5)$ & $-25.6(2.2, n=5)$ & $14.3(0.7, n=6)$ \\
\hline Filamentous cyanobacteria (winter) & $5.7(0.7, n=4)$ & $-23.1(0.4, n=4)$ & $14.8(0.8, n=3)$ \\
\hline Stenelmis (summer) & $5.3(0.2, n=7)$ & $-26.4(0.6, n=7)$ & $11.0(1.1, n=3)$ \\
\hline Stenelmis (winter) & $5.1(0.5, n=6)$ & $-27.3(0.5, n=6)$ & $10.6(0.3, n=3)$ \\
\hline Hyalella (summer) & $6.2(0.4, n=5)$ & $-24.7(0.6, n=5)$ & $12.2(1.5, n=2)$ \\
\hline Hyalella (winter) & $6.2(0.3, n=5)$ & $-26.5(1.4, n=5)$ & - \\
\hline Tryonia (summer) & $8.1(0.2, n=6)$ & $-23.1(1.0, n=6)$ & - \\
\hline Tryonia (winter) & $8.2(0.1, n=3)$ & $-23.9(0.9, n=3)$ & $11.5(1.0, n=2)$ \\
\hline Dugesia (summer) & $9.4(0.5, n=9)$ & $-23.2(0.4, n=9)$ & $10.5(1.4, n=3)$ \\
\hline Dugesia (winter) & $11.2(0.7, n=8)$ & $-25.2(0.2, n=8)$ & $10.8(0.8, n=4)$ \\
\hline Cyprinodon (summer) & $9.5(0.2, n=9)$ & $-24.8(0.7, n=9)$ & $12.4(0.9, n=9)$ \\
\hline Cyprinodon (winter) & $9.2(0.6, n=9)$ & $-28.2(1.6, n=9)$ & $10.5(1.6, n=5)$ \\
\hline Allochthonous plants (summer) & $8.2(2.5, n=3)$ & $-25.0(1.5, n=3)$ & $10.0(0.9, n=5)$ \\
\hline Allochthonous plants (winter) & $5.7(0.5, n=3)$ & $-25.1(0.1, n=3)$ & $10.1(1.3, n=5)$ \\
\hline Subm-plants (summer) & $2.7(0.3, n=4)$ & $-24.2(0.8, n=4)$ & - \\
\hline Subm-plants (winter) & $3.1(1.6, n=6)$ & $-22.6(1.5, n=6)$ & - \\
\hline Allochthonous insects (summer) & $9.6(2.1, n=3)$ & $-21.9(2.6, n=3)$ & - \\
\hline Allochthonous insects (winter) & $7.4(0.1, n=3)$ & $-22.4(0.4, n=3)$ & $6.5(0.7, n=3)$ \\
\hline
\end{tabular}

diet and $43 \%$ of winter diet. Allochthonous insects did not make a significant contribution to the diet in either season.

The model with $S$. calida as the target species showed high proportions of filamentous cyanobacteria $(58 \%)$ during summer, but $<1 \%$ during winter. A large proportion of the $S$. cal$i d a$ winter diet (95\%) was submerged allochthonous plants.

Mixing models also revealed high proportions (38\%) of C. diabolis in D. dorotocephala during winter, but considerably lower levels $(11 \%)$ during summer. Cyprinodon diabolis was trophically higher than all autochthonous invertebrates except for $D$. dorotocephala in winter when the scavenging flatworm was trophically higher than pupfish.

\section{Discussion}

Our study provides quantitative evidence that allochthonous energy sources are important to the Devils Hole food web. In Devils Hole, terrestrial plant carbon provided about $22 \%$ of the total available annual plant energy in the cavernous pool, and terrestrial insects provided 10 times more energy than aquatic invertebrates. Total annual outside energy entering Devils Hole during the study was approximately $2971 \mathrm{kj}$, compared to an estimated annual maximum of $2000 \mathrm{kj}$ of autoch- thonous algal production, or a combined total annual energy budget of about $165 \mathrm{kj} \cdot \mathrm{m}^{-2}$. This total annual energy budget is over 4.75 times lower than the total annual energy of $785 \mathrm{kj} \cdot \mathrm{m}^{-2}$ estimated by Naiman (1976) for Tecopa Bore, California, a nearby thermal artesian surface spring.

Allochthonous bat/mouse fecal pellets were more prevalent when terrestrial vegetation was most abundant from July through September with no input from October through February. These pellets quickly dissolved in the pool and therefore primarily provided nutrients for algal growth. This process may account for the relatively high nitrogen levels measured in Devils Hole. Inclusion of this fraction may be an overestimate of the total particulate energy available to invertebrate and $C$. diabolis populations in Devils Hole. Without fecal pellets, the available annual allochthonous fraction in Devils Hole is reduced to about $2364 \mathrm{kj}$.

Devils Hole received an average of about $2.5 \mathrm{~g} \mathrm{AFDM} \cdot \mathrm{m}^{-2} \mathrm{yr}^{-1}$ of allochthonous material during the study. Others have reported considerably more allochthonous input in desert aquatic ecosystems. For example, Rattlesnake Springs, a desert spring-stream in Washington, received $242 \mathrm{~g} \mathrm{AFDM} \cdot \mathrm{m}^{-2} \mathrm{yr}^{-1}$ (Cushing and Wolf 1982). The litter fall in Devils Hole was also substantially lower than that reported 
TABLE 7. Mean and relative proportions at 1 and 99 percentile ranges for different food sources for Cyprinodon diabolis, Dugesia dorotocephala, and Stenelmis calida target species. Nitrogen $\left(\delta^{15} \mathrm{~N}\right)$, carbon $\left(\delta^{13} \mathrm{C}\right)$, and sulfur $\left(\delta^{34} \mathrm{~S}\right)$ were employed using the IsoSource Model 1.3.1 provided by Phillips and Gregg (2003). Submerged plants = Eucnide urens foliage and includes only $\delta^{15} \mathrm{~N}$ and $\delta^{13} \mathrm{C}$.

\begin{tabular}{|c|c|c|c|c|c|c|}
\hline & \multicolumn{2}{|c|}{ Cyprinodon diabolis } & \multicolumn{2}{|c|}{ Dugesia dorotocephala } & \multicolumn{2}{|c|}{ Stenelmis calida } \\
\hline & summer & winter & summer & winter & summer & winter \\
\hline Cyanobacteria & $43.9(6-76)$ & $0.9(0-6)$ & $19.4(0-54)$ & $11.5(0-36)$ & $57.7(56-60)$ & $0.5(0-2)$ \\
\hline Diatom/detritus & $3.0(0-10)$ & $0.0(0-2)$ & $11.1(0-26)$ & $4.0(0-16)$ & $2.3(0-4)$ & $0.0(0-0)$ \\
\hline Stenelmis calida & $14.8(0-52)$ & $50.5(40-60)$ & $14.7(0-50)$ & $11.3(0-36)$ & - & - \\
\hline Hyalella sp. & $16.0(0-64)$ & $7.7(0-20)$ & $17.2(0-58)$ & $3.4(0-14)$ & $0.7(0-2)$ & $3.6(0-8)$ \\
\hline Tryonia variegata & $2.1(0-10)$ & $2.1(0-10)$ & $5.1(0-20)$ & $14.3(0-48)$ & $0.0(0-0)$ & $0.0(0-0)$ \\
\hline Dugesia dorotcephala & $7.1(0-28)$ & $34.8(28-46)$ & - & - & $0.0(0-0)$ & $0.0(0-0)$ \\
\hline Cyprinodon diabolis & - & - & $10.5(0-36)$ & $37.7(12-66)$ & $0.0(0-0)$ & $1.0(0-4)$ \\
\hline Allochthonous plants & $9.0(0-36)$ & $2.6(0-12)$ & $11.2(0-42)$ & $10.0(0-40)$ & $0.0(0-0)$ & $72.9(66-80)$ \\
\hline Submerged plants & $2.2(0-10)$ & $0.5(0-4)$ & $6.0(0-20)$ & $2.4(0-10)$ & $39.3(38-40)$ & $22.0(20-26)$ \\
\hline Allochthonous insects & $1.9(0-10)$ & $0.9(0-6)$ & $4.8(0-18)$ & $5.4(0-22)$ & $0.0(0-0)$ & $0.0(0-0)$ \\
\hline
\end{tabular}

for most streams located in desert scrub zones (Cushing 1996, Benfield 1997). The lower input of terrestrial litter in Devils Hole is due to the cavernous nature of the system, the limited terrestrial vegetation on the walls of the cavern, and the sparse surrounding desert terrain. Naiman (1976) reported negligible outside energy in Tecopa Bore.

The stochastic rain event on 3 September 2001 contributed over 1.2 times more fine and coarse carbon to Devils Hole in 1 hour than was estimated from funnel traps for the entire year. This was obviously an underestimate because samples were collected 2 days after the event. Although the fate of this supplemental carbon in Devils Hole is not known, this source of energy may have greater influence on variations in the size of the pupfish population in Devils Hole and on desert aquatic ecosystems in general than has been realized heretofore.

The importance of allochthonous plant carbon in the Devils Hole ecosystem was corroborated by mixing models. Tissues of $C$. diabolis had incorporated components derived from cyanobacteria in the summer, but shifted to the collector/gathering insect, S. calida, during the winter. Mixing models using S. calida showed a higher utilization of allochthonous plant carbon during the winter. These results suggest the change in pupfish diet during the winter was an indirect shift of allochthonous energy sources mediated by the diet shift in S. calida. Models showed the limited role of allochthonous insects in the Devils Hole food web, and agreed with observations on gut contents. The models also showed limited utilization of $T$. variegata by $C$. diabolis in both winter and summer even though this gastropod made up over $82 \%$ of the aquatic invertebrate mass. This model result also agreed with observations on gut contents.

The seasonally high percentage $(>52 \%)$ of $\mathrm{CaCO}_{3}$ crystals in the pupfish gut suggests a very inefficient expenditure of energy by pupfish and places additional constraints on the pupfish population. Minckley and Deacon (1975) also found $\mathrm{CaCO}_{3}$ crystals to be the dominant item in $C$. diabolis stomachs.

The increased tolerance values required in mixing models for $S$. calida may suggest an unknown carbon source that was not included in our models. A potential unmeasured energy source in the light-limited Devils Hole ecosystem may be microbial biofilms. Recently, Simon et al. (2003) demonstrated that biofilms were important energy sources for invertebrate communities in light-limited cave streams, even in the presence of abundant coarse particulate organic matter. Similar energy sources may be utilized in the light-limited Devils Hole ecosystem and may account for unknown carbon sources in its food web.

We estimated that the pool at Devils Hole received $<30 \%$ of the total annual solar radiation received by the surface spring of Tecopa Bore (Hutchinson 1957, Naiman 1976). The autochthonous algal production in Devils Hole was nearly 2 orders of magnitude lower than that reported for a desert spring-stream in Washington (Cushing and Wolf 1984), and 200fold lower than reported for Tecopa Bore (Naiman 1976). The annual mean gross primary 
production was also substantially below the annual mean $\left(2.95 \mathrm{~kg} \mathrm{C} \cdot \mathrm{yr}^{-1}\right)$ for desert streams in North America (Lamberti and Steinman 1997).

The photosynthetic efficiency during winter indirect light was over twice that for summer direct light conditions in Devils Hole. This may be due to highly efficient photoreceptor systems in the dominant filamentous cyanobacteria (Krogmann 1973). In addition, cyanobacteria are better suited for the lower concentrations of dissolved oxygen and higher temperatures that are prevalent in Devils Hole (Carr and Whitton 1973).

Autochthonous algal production was reduced by nearly $80 \%$ and allochthonous carbon entry was reduced by nearly $96 \%$ during winter compared to summer. The low autochthonous and allochthonous carbon during winter puts major constraints on the potential size of individual fish and on the overall size of the endemic C. diabolis population in Devils Hole. No more than 553 fish have been reported in Devils Hole since 1972, with the population averaging $<225$ fish over the last decade (D. Threloff, Ventura, CA, personal communication; Manning, Death Valley National Park, CA, personal communication).

Based on isotopic mixing models, the flatworm, D. dorotocephala, utilized $C$. diabolis tissue: possibly dead pupfish, eggs, or even prolarvae. Observations during the study suggested there were greater numbers of $C$. diabolis and $D$. dorotocephala in the shallow water on the shelf. Therefore, drawdown in water levels could be detrimental to the pupfish population, because it may create overlapping habitats for both flatworms and pupfish.

This is the 1st study to show a linkage between allochthonous carbon and an endangered fish species. Allochthonous carbon provides an important energy source for sustaining the food web in the incised Devils Hole ecosystem. Climatic conditions that affect autochthonous production, and especially allochthonous production, in the vicinity of Devils Hole are critical to the food web in Devils Hole. Any increases in atmospheric particulate material from dust storms or atmospheric pollution would further reduce the solar energy and further reduce algal autochthonous production. Also, any reduction in precipitation in the area would reduce production of terrestrial vegeta- tion, and consequently decrease potential allochthonous energy. Torrential desert rains also appear important in delivering large amounts of allochthonous energy to this desert aquatic ecosystem. Long-term climatic cycles, as well as seasonal cycles of precipitation, especially stochastic precipitation events, may have greater influence on variations in food webs in aquatic desert ecosystems than has heretofore been appreciated.

\section{ACKNOWLEDGMENTS}

We thank Douglas Threloff for organization of the study, logistical assistance, and collection of light data and funnel traps during the project. Linda Manning (Death Valley National Park) assisted with field activities, and with collection of light data, funnel traps, and allochthonous material after the rain event. We also thank David Herbst (Sierra Nevada Aquatic Research Laboratory, Mammoth Lakes, CA) for assistance with invertebrate identifications and Heather Gavette for processing samples. SCUBA divers Tom Justskulsky and Jerry Stein collected data throughout a $26-\mathrm{m}$ depth profile; Allen Haden ran the application of Isosource mixing models; and Michael Yard determined dissolved organic carbon values. Charles van Riper, III, and Mark Sogge were facility contact persons. We also thank James Deacon, Allen Haden, David Herbst, Linda Manning, Joe Shannon, and Douglas Threloff for their helpful comments on earlier drafts. Finally, we thank C.E. Cushing, Mark C. Belk, and 1 anonymous reviewer for their helpful comments on the final manuscript. Funds for this project were provided by the USGS Resource Division (Project \#99175HS001). All activities on this project were conducted under Federal Fish and Wildlife Permit TEO14999-0.

\section{Literature Cited}

Benfield, E.F. 1997. Comparison of litterfall input to streams. Pages 104-108 in J.R. Webster and J.L. Meyer, editors, Stream organic matter budgets. Journal of the North American Benthological Society 16.

Bosley, K.L., AND S.C. WAINRIGHT. 1999. Effects of preservatives and acidification on the stable isotope ratios $\left({ }^{15} \mathrm{~N}:{ }^{14} \mathrm{~N},{ }^{13} \mathrm{C}:{ }^{12} \mathrm{C}\right)$ of two species of marine animals. Canadian Journal of Fisheries and Aquatic Sciences 56:2181-2185.

BotT, T.L. 1996. Primary productivity and community respiration. Pages 533-556 in F.R. Hauer and G.A. Lamberti, editors, Methods in stream ecology. Academic Press, San Diego, CA. 
Bott, T.L., J.T. Brock, C.E. Cushing, S.V. Gregory, D. King, AND R.C. Petersen. A comparison of methods for measuring primary production and community respiration in streams. Hydrobiologia 60:3-12.

Carr, N.G., AND B.A. WhitTon. 1973. The biology of bluegreen algae. Botanical Monographs 9. University of California Press, Berkeley.

Clesceri, L.S., A.E. Greenberg, and A.D. Eaton. 1998. Standard methods for the examination of water and wastewater. 20th edition. American Public Health Association, Washington, DC.

Cummins, K.W. 1974. Structure and function of stream ecosystems. BioScience 24:631-641.

Cushing, C.E. 1996. The ecology of cold desert springstreams. Archiv für Hydrobiologie 135:499-522.

1997. Organic matter dynamics in Rattlesnake Springs, Washington, USA. Pages 39-46 in J.R. Webster and J.L. Meyer, editors, Stream organic matter budgets. Journal of the North American Benthological Society 16.

Cushing, C.E., AND E.G. WoLF. 1982. Organic energy budget of Rattlesnake Springs, Washington. American Midland Naturalist 107:404-407.

1984. Primary production in Rattlesnake Springs, a cold desert spring-stream. Hydrobiologia 114:229 236.

Deacon, J.E., and C. Williams. 1991. Ash Meadows and the legacy of the Devils Hole pupfish. Pages 69-87 in W.L. Minckley and J.E. Deacon, editors, Battle against extinction. University of Arizona Press, Tucson.

Fisher, S.G., AND G.E. Likens. 1973. Energy flow in Bear Brook, New Hampshire: an integrative approach to stream ecosystem metabolism. Ecological Monographs 43:421-439.

Gustafson, E.S., and J.E. Deacon. 1998. Distribution of larval Devils Hole pupfish, Cyprinodon diabolis Wales, in relation to dissolved oxygen concentration in Devils Hole. Final report, Death Valley National Park, 1 April 1998.

Herbst, D.B. 2003. Devils Hole benthic invertebrate community dynamics: distribution, seasonality and production. Final report provided to Death Valley National Park. 32 pp.

Hutchinson, G.E. 1957. A treatise on limnology. Volume 1. John Wiley \& Sons, New York.

Krogmann, D.W. 1973. Photosynthesis reactions and components of thylakoids. Pages 80-98 in N.G. Carr and B.A. Whitton, editors, The biology of blue-green algae. Botanical Monographs 9. University of California Press, Berkeley.

LAmberti, G.A., AND A.D. STEINMAn. 1997. A comparison of primary production in stream ecosystems. Pages 95-104 in J.R. Webster and J.L. Meyer, editors, Stream organic matter budgets. Journal of the North American Benthological Society 16.

Mantel, S.K., M. Salas, and D. Dudgeon. 2004. Food web structure in a tropical Asian forest stream. Journal of the North American Benthological Society 23:728-755.

MinagaWA, M., AND E. Wada. 1984. Stepwise enrichment of ${ }^{15} \mathrm{~N}$ along food chains: further evidence and the relation between $\delta^{15} \mathrm{~N}$ and animal age. Geochimica et Cosmochimica Acta 48:1135-1140.
Minckley, C.O., AND J.E. Deacon. 1975. Foods of the Devils Hole pupfish, Cyprinodon diabolis (Cyprinodontidae). Southwestern Naturalist 20:105-111.

MinshaLL, G.W. 1967. Role of allochthonous detritus in the trophic structure of a woodland springbrook community. Ecology 48:139-149.

Naiman, R.J. 1976. Primary production, standing stock, and export of organic matter in a Mohave Desert thermal stream. Limnology and Oceanography 21:60-73.

ODum, H.T. 1957. Trophic structure and productivity of Silver Springs. Ecological Monographs 27:55-112.

Peterson, B.J., And B. Fry. 1987. Stable isotopes in ecosystem studies. Annual Review of Ecological Systems 18:293-320.

Phillips, D.L., AND J.W. GregG. 2003. Source partitioning using stable isotopes: coping with too many sources. Oecologia 136:261-269.

Riggs, A.C., And J.E. Deacon. 2004. Connectivity in desert aquatic ecosystems: the Devils Hole story. In D.W. Sada, editor, Spring-fed wetlands conference symposium. Desert Research Institute, Las Vegas, NV. Available from: http://www.wetlands.dri.edu

RuncK, C., AND D.W. BLINN. 1994. Role of Belostoma bakeri (Heteroptera) in the trophic ecology of a fishless desert spring. Limnology and Oceanography 39: $1800-1812$.

SAS Institute, INC. 1989-1999. JMP-statistics, student version. SAS Institute, Inc., Cary, NC.

Shepard, W.D., D.W. Blinn, R.J. HofFman, and P.T. Kantz. 2000. Algae of Devils Hole, Nevada, Death Valley National Park. Western North American Naturalist 60:410-419.

Simon, K.S., E.F. Benfield, And S.A. Macko. 2003. Food web structure and the role of epilithic biofilms in cave streams. Ecology 84:2395-2406.

Soltz, D.L., AND R.J. NAIMAN. 1978. The natural history of native fishes in the Death Valley system. Science Series 30, Natural History Museum of Los Angeles County. 76 pp.

TEAL, J.M. 1957. Community metabolism in a temperate cold spring. Ecological Monographs 27:293-302.

TILly, L.J. 1968. Structure and dynamics of Cone Spring. Ecological Monographs 38:169-197.

[USEPA] United States Environmental Protection Agency. 1993. Methods for determination of inorganic substances in environmental samples. EPA-600/R-93/100. Method 365.1.

Vander Zanden, M.J., and J.B. Rasmussen. 2001. Variation in $\delta^{15} \mathrm{~N}$ and $\delta^{13} \mathrm{C}$ trophic fractionation: implications for aquatic food web studies. Limnology and Oceanography 46:2061-2066.

WetzeL, R.G. 2001. Limnology: lake and river ecosystems. 3rd edition. Academic Press, San Diego, CA.

WiLsON, K.P. 2001. Role of allochthonous and autochthonous carbon in the food web of Devils Hole, Nevada. Master's thesis, Department of Biological Sciences, Northern Arizona University, Flagstaff.

Received 27 February 2006 Accepted 16 October 2006 